\title{
Impact of Treasury Single Account on the Performance of the Banking Sector in Nigeria
}

\author{
${ }^{1}$ Ndubuaku Victor C., ${ }^{2}$ Ohaegbu O.K., ${ }^{3}$ Nina Nsimoh M. \\ ${ }^{1,2,3}$ Department of Accountancy, Federal College of Agriculture Ishiagu, Ebonyi State, Nigeria.
}

\begin{abstract}
Treasury Single Account (TSA) was introduced to curb corruption in the country's public accounting system with its attendant impact on the banking sector. This research study aims to determine the impact of TSA on the performance of the banking system in Nigeria. This research study sought to determine the impact of TSA on Credit to the Private Sector, Deposit mobilization and Loans and Advances respectively. Secondary and time series data were obtained from the CBN statistical bulletin 2015. The data were analysed using regression and correlation analysis. The results from the research analysis confirmed that the TSA had a significant impact on Credit to the Private Sector, Deposit Mobilization and Loans and Advances.
\end{abstract}

Keywords: Treasury Single Account, Deposit Mobilization, Credit to the Private Sector, Loans and advances, Financial Performance, Banking Sector

\begin{abstract}
Disclosure Statement
I, NDUBUAKU VICTOR CHIJIOKE hereby certify that I have no conflicting affiliations with or involvement in any organization or entity with any financial interest (such as honoraria; educational grants; participation in speakers' bureaus; membership, employment, consultancies, stock ownership, or other equity interest; and expert testimony or patent-licensing arrangements), or non-financial interest (such as personal or professional relationships, affiliations, knowledge or beliefs) in the subject matter or materials discussed in this manuscript.

Signed: NDUBUAKU VICTOR CHIJIOKE,

Dated: Oct 1, 2016
\end{abstract}

I, OHAEGBU KINGSLEY O. hereby certify that I have no conflicting affiliations with or involvement in any organization or entity with any economic and financial interest (such as honoraria; educational grants; participation in speakers' bureaus; membership, employment, consultancies, stock ownership, or other equity interest; and expert testimony or patent-licensing arrangements), or non-financial interest (such as personal or professional relationships, affiliations, knowledge or beliefs) in the subject matter or materials discussed in this manuscript.

Signed: OHAEGBU KINGSLEY O.,

Dated: Oct 1, 2016

I, NINA NSIMOH M certify that I have no conflicting affiliations with or involvement in any organization or entity with any economic and financial interest (such as honoraria; educational grants; participation in speakers' bureaus; membership, employment, consultancies, stock ownership, or other equity interest; and expert testimony or patent-licensing arrangements), or non-financial interest (such as personal or professional relationships, affiliations, knowledge or beliefs) in the subject matter or materials discussed in this manuscript.

Signed: NINA NSIMOH M,

Dated: Oct 1, 2016

\section{Introduction}

The banking sector is the engine of any nation's economy. The economic status of any nation depends on how stable their banking industry is. In other words, any issue that affects banks also has an impact on the economy of the nation (Kanu, 2016). In Nigeria, commercial banks have been the custodians of government funds. The banking system in Nigeria has experienced several reforms and policies, some favourable, others unfavourable. Many banks did not survive these reforms. Until the introduction of TSA, government Ministries, Departments and Agencies (MDA's) operated a multiplicity of accounts in the commercial banks. The MDA's use part of the funds they generated to fund their operation and remitted the residual to the federation account.

This resulted in leakages, embezzlement of funds and inadequate budgetary and financial planning. However the highest beneficiaries of this situation were the banks who relied on deposits from government agencies and lent back to the government at high interest rates. The banks however, operated "arm chair banking" as they no longer mobilized funds from other sectors of the economy.

In light of these, the federal government directed all MDA's to close their accounts with commercial banks and transfer the balances into the federation account with the Central Bank of Nigeria which was conveyed in a CBN circular no BPS/CSO/CON/DIR/01/079; dated, February 25,2015 and addressed to all 
Deposit Money Banks (DMB). The circular was titled “Commencement of Federal Government's Independent Revenue Collection Scheme under the Single Treasury Account (TSA) Initiative".

The TSA is a Unified structure of government bank accounts enabling consolidation and optimal utilization of government cash resources. Through this bank account or set of linked bank accounts, the government transacts all its receipts and payments and gets a consolidated view of its cash position at any given time (Yusuf, 2016).

Prior to the introduction to TSA, Nigeria had fragmented banking arrangement for revenue and payment transactions. These were more than 10,000 bank accounts in multiple banks which made it impossible to establish government consolidated cash position at any point in time. It led to pockets of idle cash balances held in MDA's account when government was out borrowing money (Obinna, 2015). (Yusuf, 2016) added that "the maintenance of Treasury Single Account will help ensure proper cash management by eliminating idle funds usually left with different commercial banks and in a way enhance reconciliation of revenue collection and payment

\subsection{Problem Statement}

A great challenge facing most parts of the world and, particularly, the developing countries like Nigeria is how to achieve efficient allocation of resources as well as stabilization of the business cycles. An important factor for efficient management and control of government's cash resources is a unified structure of government banking. Such unified banking arrangements should be designed to minimize the cost of government borrowing and maximize the opportunity cost of cash resources. This requires that cash received is available for carrying out government's expenditure programmes and making payments in a timely manner. Many emerging markets and low-income countries have fragmented systems for handling government receipts and payments. In these countries, the ministry of finance/treasury lacks a unified view and centralised control over government's cash resources. As a result, this cash lies idle for extended periods in numerous bank accounts held by spending agencies while the government continues to borrow to execute its budget. It is based on these reasons that the current global revolution in government accounting became paramount following which Nigeria has initiated and implemented the Treasury Single Account (TSA) and other series of economic policies to assist in the better management of her economy.

\subsection{Objectives Of The Study}

The aim of this research study is to determine the impact of TSA on the performance of the banking sector in Nigeria. Since TSA presently covers the federal level, the study sought to determine:

1. Whether Federal Government Deposit (FG Dp) in commercial banks had any significant impact on credit to the private sector

2. Whether Federal Government Deposit (FG Dp) had any significant impact on deposit mobilization of Commercial Banks

3. Whether Federal Government Deposit (FG Dp) in commercial banks had any significant impact on Loan and Advances to the economy

\subsection{Hypothesis Of The Study}

The Null hypothesis of the study is formulated in view of the above objectives;

1. There is no significant impact of Federal Government Deposit (FG Dp) on credit to the private sector.

2. There is no significant impact of Federal Government Deposit (FG Dp) on deposit mobilization

3. There is no significant impact of Federal Government Deposit (FG Dp) on loans and advances

\subsection{Significance Of The Study}

The result from this study would go a long way to enlighten the policy makers and the government on the impact of TSA on the banking system and would also serve as an input and guide to policy formulation. Because this topic is reasonably new, it would help the public understand fully the impact of TSA, it pros and cons and its effect on the economy. It would also contribute knowledge to literature for scholars and researchers interested in carrying out further research.

This paper is structured into five parts namely: Part 1; Introduction, Part 2; Literature Review, Part 3; Research Methodology, Part 4; Analysis and Implications of Findings, Part 5; Conclusion and Recommendation

\subsection{Conceptual Framework}

Treasury Single Account (TSA) is one of the financial policies implemented by the federal government of Nigeria to consolidate all the revenue from all MDA's in the country by way of deposit into commercial banks traceable into a single account at the Central Bank of Nigeria (Kanu, 2016) 
Section 80 (1) of the 1999 Constitution as amended states that "all revenue or other money raised or received by the Federation (not being revenue or other money payable under this Constitution or any Act of the National Assembly into any other public fund of the Federation established for a specific purpose) shall be paid into and form one Consolidated Revenue Fund of the Federation".

IMF, (2010) highlighted three essential features of TSA:

- First, the government banking arrangement should be unified, to enable the ministry of Finance (MoF) (or treasury) to have an oversight responsibility for, over government cash flows in and out of these bank accounts.

- Second, no other government agency operates bank accounts outside the treasury single account arrangement.

- Third, the consolidation of resources should be comprehensive, and encompass all funds both budgetary and extra-budgetary.

Therefore, the TSA is a payment system in which all revenues due to the government are paid into a unified account domiciled with the $\mathrm{CBN}$. Its objective is to ensure fiscal discipline and transparent management of the nation's finances. (Kanu, 2016)

According to (Yusuf, 2016), TSA is a unified structure of government bank accounts enabling consolidation and optimal utilization of government cash resources. It is a bank account or a set of linked bank accounts through which the government transacts all its receipts and payments and gets a consolidated view of its cash position at any given time. This presidential directive would end the previous public accounting situation of several fragmented accounts for government revenues, incomes and receipts, which in the recent past has meant the loss or leakages of legitimate income meant for the federation account. The TSA is a process and tool for effective management of government's finances, banking and cash position. In accordance with the name, it pools and unifies all government accounts through a single treasury account.

The advantages and benefits of the TSA are legion. The consolidation into a TSA paves way for the timely capture and payment of all due revenues into government coffers without the intermediation of multiple banking arrangements. This prevents revenue leakages in terms of revenue loss and mismanagement by operators of all revenue-generating agencies. With this comes better cash management practices since the Treasury can at all times have an overall view of government's cash position, as against the fragmented positions of different Ministries, Department and Agencies (MDAs), which need to be laboriously pooled together to get the overall picture. This will reduce the cost of borrowing by government and its agencies, as the government will likely be in the surplus at most times of the year. Take the example of the practice before the TSA, MDA 'A', based on budgetary releases could have surplus cash (meaning cash that is not immediately required) in its bank accounts whilst, MDA 'B', which needs immediate cash for urgent transactions is cash starved and has little or nothing in its account. Although, MDA 'B' has approvals in the budget for transaction, it has no immediate cash. MDA ' $\mathrm{B}$ ' is likely to borrow from a bank at an interest to carry out the urgent assignment, thereby incurring costs to Treasury, whilst treasury finances lie idle in MDA 'A'. This would no longer happen.

For (Eme, Chukwurah, \& Iheanacho, 2015), A Treasury Single Account (TSA) is a network of subsidiary accounts all linked to a main account such that, transactions are effected in the subsidiary accounts but closing balances on these subsidiary accounts are transferred to the main account, at the end of each business day.

According to (Yusuf \& Chiejina, 2015), a Treasury Single Account is a unified structure of government bank account enabling consolidation and optimal utilisation of government cash resources. It is a bank account or a set of linked bank accounts through which the government transacts all its receipts and payments and gets a consolidated view of its cash position at any given time. A TSA therefore is considered a prerequisite for modern cash management and is an effective tool for the ministry of finance/treasury to establish oversight and centralized control over government's cash resources.

According to (Lienert, 2009), A Treasury Single Account (TSA) is a unified structure of government bank accounts that gives a consolidated view of government cash resources. Based on the principle of unity of cash and the unity of treasury, a TSA is a bank account or a set of linked accounts through which the government transacts all its receipts and payments

The primary objective of a TSA is to ensure effective aggregate control over government cash balances. The consolidation of cash resources through a TSA aggregate control of cash is also a key element in monetary and budget management (Isa, 2016)

\subsection{Diffusion of Innovations Theory}

Diffusion of innovations is a theory that seeks to explain how, why, and at what rate new ideas and technology spread through cultures (Richard, Florence, \& Zénon, 2015). (Rogers, 1995) explained diffusion as the process 
by which an innovation is communicated through certain channels over time among the participants in a social system. The origins of the diffusion of innovations theory are varied and span multiple disciplines. The four main elements of diffusion are the innovation, communication channels, time, and the social system. Diffusion is a special type of communication, in which the messages are concerned with a new idea. It is this newness of the idea in the message content of communication that gives diffusion its special character. This process consists of a series of actions and choices over time through which an individual or an organization evaluates a new idea and decides whether or not to incorporate the new idea into ongoing practice. This behaviour consists essentially of dealing with the uncertainty that is inherently involved in deciding about a new alternative to those previously in existence. It is the perceived newness of the innovation, and the uncertainty associated with this newness, that is a distinctive aspect of innovation decision making (Rogers, 1995). This theory is related to the study as it presents the process of newness, implementation and consequences of the innovation as regards the Treasury Single Account (TSA) policy.

\subsection{TSA And The Banking System}

In Nigeria, commercial banks have been the custodians of government funds (Kanu, 2016). Therefore, with the maintenance of a single account, banks will be deprived of the free flow of funds from ministries. Indeed, it is estimated that commercial banks hold about N2.2 trillion public sector funds at the beginning of the first quarter of 2015. When such amount of money leaves the system is obvious. When one considers the fact that each time the monthly federal allocation is released, the banking system is usually awash with liquidity, and as soon as this public sector fund dries up, the result is liquidity problem with an increase in interbank rates. The banks must be affected, when such high revenue generating parastatals like the NNPC moves out of commercial banks (Kanu, 2016). Commercial banks will be tremendously affected by the Treasury Single Account policy. This would cause insufficiency of available cash in the banking system, resulting in a surge in money market rates during the period as banks source for funds to cover their poor liquidity positions. Indeed, the Nigerian banking industry, on an aggregate basis, would be affected regarding deposits and funding cost structure (Kanu, 2016). As a matter of fact, TSA generated much fear in the banking industry even before its implementation. The fear is that with the high Monetary Policy Rate at 13\%, Cash Reserve Ratio (CRR) at $20 \%$ and $75 \%$ available for private and public sector deposits respectively, its implementation would not be favourable to banks. Irrespective of how tough his policy will be on banks, it will perhaps compel the banks to focus on the funds of the real sector of the economy, rather than spending much on Federal Government projects, Oil \& Gas Transactions, Forex dealings, etc. Any commercial bank that fails to operate based on the core banking functions for which they were licensed must definitely close shop. This will cause heavy downsizing of staff, thereby increasing the unemployment rate in the country. Managements of banks should understand the aim of establishing banks. The Government is not only customer banks have. The issue of banks chasing government money at the expense of other clients especially in the sector of the economy is a questionable commentary on the performance of the banks (Kanu, 2016). The Guardian of August 16, 2015 argued that "the full implementation of the TSA will certainly reduce the banks' net liquidity position and hence constrain their ability to create credits and this will invariably affect their profitability (Tari, Pwafeyeno, \& Minnessi, 2016). However, (Ocheni, 2016) opines that the full implementation of the TSA will not be hurting banks. It will only hurt establishments that purport and pretend to be banks but have failed, refused and neglected to understand banking and do what bankers do elsewhere. It is an opportunity for banks to refocus on the original purposes for which they were set up to collect depositors' funds, keep them safe; engage in intermediation to create wealth and jobs for the economy and in the process earn profit for themselves

\subsection{Benefits And Challenges Of TSA}

The former Accountant General of the Federation (A.G.F), Jonah Otunla, backed the implementation of the TSA and said it would remove the ambient secrecy in the management of public finance in MDA's. Under the guise of non-descript official secrecy, government staff and politicians have been known to employ all sorts of administrative devices and illegal liaisons to engage in business ventures for private gains using government money and thereby frustrating proper execution of projects as well as causing salary delays. Furthermore, agencies defraud government by siphoning government funds through multiple bank accounts unknown to the authorities. The implementation of the TSA would make it difficult for this monumental fraud to continue undetected. It also affords the government an oversight of funds pooled into the TSA by generating agencies.

The IMF in a 2010 paper titled "Treasury Single Account: Concept, Design, and Implementation Issues", outlined the benefits of operating a Treasury Single Account. It started by explaining that the primary objective of a TSA is to ensure effective aggregate control over government cash balances. Here are the benefits:

- Allows complete and timely information on government revenue in countries with advanced payment and settlement systems and an Integrated Financial Management Information System (IFMIS) with adequate 
interfaces with the banking system, this information will be available in real time. As a minimum, required and updated balances should be available daily.

- Improves appropriation control. The TSA ensures that the MoF has full control over budget allocations, and strengthens the authority of the budget appropriation. The result of maintaining separate bank accounts is often system, where funds provided for budgetary appropriations are augmented by additional cash resources that become available through various creative, often extra-budgetary, measures.

- Improves operational control during budget execution. When the Treasury has full information about cash resources, it can plan and implement budget in an efficient, transparent, and reliable manner. The existence of uncertainty regarding whether the Treasury will have sufficient funds to finance program expenditures may lead to sub-optimal behaviour by budget entities, such as exaggerating their estimates for cash needs or channelling costs through off-budget arrangements.

- Enables efficient fund management. TSA facilitates regular monitoring of government cash balances. It also enables higher quality inflow and out flow analysis to be undertaken (e.g., identifying causal factors of variances and distinguishing causal factors from random variations in cash balances.

- Elimination of bank fees and transaction costs. Reducing the number of bank accounts results in a lower administrative cost for the government for maintaining these accounts, including the cost associated with bank reconciliation, and reduced banking fees.

- Facilitates efficient payment mechanisms. TSA ensures that there is no ambiguity regarding the volume or the location of the government funds, and makes it possible to monitor payment mechanisms precisely. It can result in substantially lower transaction costs because of economies of scale in processing settlements. In establishment of a TSA, it is combined with the elimination of the "float" in the banking and the payment systems, and the introduction of transparent fee and penalty structures for payment services. Many governments have achieved substantial reductions in their real cost of banking services by introducing a TSA system.

- Improves bank reconciliation and quality of fiscal accounting system. TSA allows for effective reconciliation between the government accounting systems and cash flow statements from the banking system. TSA also eliminates the risk of errors in reconciliation of financial statements and improves the timeliness and quality of the fiscal accounts.

- Lowers liquidity reserve needs. TSA reduces the speedy depletion of cash flows through the treasury, thus allowing it to maintain a lower cash reserve/buffer to meet unexpected fiscal volatility.

\section{Research Methodology}

This research study employed descriptive and ex post facto research design. The population of the study is made up of the 24 banks in Nigeria. The Time Series data used for the study was obtained from secondary sources such as the Central Bank of Nigeria Statistical Bulletin. The study covered data from the period 2010-2015. Regression and correlation analysis were used to analyze the data.

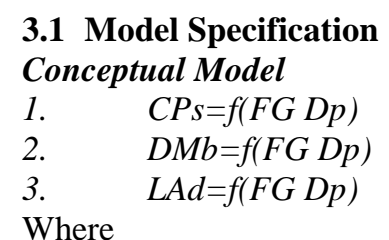

CPs $=$ Credit to the Private Sector

$\mathrm{DMb}=$ Deposit Mobilisation

LAd $=$ Loans and Advances

FG Dp= Federal Government Deposit

Analytical Model

1. $C P s=\alpha+\beta(F G D p)+\varepsilon$

2. $D M b=\alpha+\beta(F G D p)+\varepsilon$

3. $L A d=\alpha+\beta(F G D p)+\varepsilon$

Where

$\alpha=$ Intercept

$\beta=$ Coefficient of the explanatory variable (slope)

$€=$ Represents the error term in the model 


\section{Data Analysis, Results and Interpretations}

This chapter presents the data analysis, interpretation and discussion of the research findings. The collected data were analysed and interpreted in line with the aim of the study which is to determine the impact of Treasury Single Account on the performance of the banking industry in Nigeria.

Regression and correlation analysis were used to determine the relationship between TSA \{represented by Federal Government Deposits (FG Dp) $\}$ and performance of the Commercial Banks in Nigeria (represented by Deposit Mobilization, Credit to the Private Sector and Loans and Advances).

\section{Hypothesis 1:}

There is no significant impact of Federal Government Deposit (FG Dp) on credit to the private sector.

Table 1: Showing Regression, Correlation analysis between FG Deposits and Credit to the Private sector

\section{Coefficients $^{\mathrm{a}}$}

\begin{tabular}{|ll|l|l|l|l|l|}
\hline \multirow{2}{*}{ Model } & \multicolumn{2}{|l|l|l|}{ Unstandardized Coefficients } & Standardized Coefficients & & \\
\cline { 3 - 6 } & & $\mathrm{B}$ & Std. Error & Beta & $\mathrm{t}$ & Sig. \\
\hline 1 & (Constant) & 4580.233 & 1671.147 & & 2.741 & .016 \\
& FG Deposit (N'b) & 5.317 & 1.931 & .593 & 2.753 & .016 \\
\hline
\end{tabular}

a. Dependent Variable: Credit to Private Sector (N'b)

Source: Research Finding 2016

Regression Model

$C P s=4580.233+5.317(F G D p)$

The regression model explains that Federal Government Deposit (FG Dp) has a positive relationship with Credit to the Private Sector (CrP). An increase in One Naira of FG Dp would lead to a proportionate increase of 5.317 Naira and vice versa.

The correlation coefficient of 59.3 percent indicates a strong positive relationship between Federal Government Deposit and Credit to the Private Sector.

The $P$ value was 0.016 which was less 0.05 means that the $P$ value is statistically significant at $5 \%$ level. Since $t_{\text {cal }}$ (2.753) is outside our acceptance region $(+/-1.96)$, we therefore reject the null hypothesis and uphold the alternative hypothesis. That is, there is a significant impact of FG Deposit on credit to the private sector.

Therefore the TSA policy which seeks to reduce FG Deposit in the Commercial banks would significantly reduce Credit to the Private Sector which agrees with Kanu (2016).

\section{Hypothesis 2:}

There is no significant impact of Federal Government Deposit (FG Dp) on Deposit Mobilization

Table 2: Showing Regression, Correlation analysis between FG Deposits and Deposit Mobilization Coefficients $^{\mathrm{a}}$

\begin{tabular}{|c|c|c|c|c|c|}
\hline \multirow[b]{2}{*}{ Model } & \multicolumn{2}{|c|}{ Unstandardized Coefficients } & \multirow{2}{*}{\begin{tabular}{|l} 
Standardized Coefficients \\
Beta
\end{tabular}} & \multirow[b]{2}{*}{$\mathrm{t}$} & \multirow[b]{2}{*}{ Sig. } \\
\hline & B & Std. Error & & & \\
\hline 1 (Constant) & 2995.263 & 1072.146 & & 2.794 & .014 \\
\hline FG Deposit (N'b) & 2.881 & 1.239 & .528 & 2.325 & .036 \\
\hline
\end{tabular}

Source: Research Finding 2016

Regression Model

$D p M=2995.263+2.881(F G D p)$

The regression model explains that Federal Government Deposit (FG Dp) has a positive relationship with Deposit Mobilization (DpM). An increase in One Naira of FG Dp would lead to a proportionate increase of 2.881 Naira of (DpM) and vice versa. The correlation coefficient of 52.8 percent indicates a strong positive relationship between Federal Government Deposit and Deposit Mobilization (DpM).

The $P$ value was 0.036 which was less than 0.05 means that the $P$ value is statistically significant at $5 \%$ level. Since $t_{\text {cal }}(2.325)$ is outside our acceptance region $(+/-1.96)$, therefore we reject the null hypothesis and uphold the alternative hypothesis. That is, there is a significant impact of FG Deposit on Deposit Mobilization (DpM).

Therefore the TSA policy which seeks to reduce FG Deposit in the commercial banks would significantly reduce Deposit Mobilization (DpM) which agrees with Kanu, 2016. 


\section{Hypothesis 3:}

There is no significant impact of Federal Government Deposit (FG Dp) on Loans and Advances

Table 3: Showing Regression, Correlation analysis between FG Deposits and Loans and Advances Coefficients $^{\mathrm{a}}$

\begin{tabular}{|c|c|c|c|c|c|c|}
\hline \multirow{2}{*}{\multicolumn{2}{|c|}{ Model }} & \multicolumn{2}{|c|}{ Unstandardized Coefficients } & $\begin{array}{l}\text { Standardized } \\
\text { Coefficients }\end{array}$ & \multirow[b]{2}{*}{$\mathrm{t}$} & \multirow[b]{2}{*}{ Sig. } \\
\hline & & B & Std. Error & Beta & & \\
\hline \multirow[t]{2}{*}{1} & (Constant) & 4150.694 & 1203.429 & & 3.449 & .004 \\
\hline & FG Deposit (N'b) & 2.980 & 1.391 & .497 & 2.143 & .050 \\
\hline
\end{tabular}

a. Dependent Variable: Loans and Advances (N'b)

Source: Research Finding 2016

Regression Model

$L A d=4150.694+2.980(F G D p)$

The regression model explains that Federal Government Deposit (FG Dp) has a positive relationship with Loans and Advances (LAd). An increase in One Naira of FG Dp would lead to a proportionate increase of 2.980 Naira of (LAd) and vice versa. The correlation coefficient of 49.7(approx. 50 percent) indicates a moderate and positive relationship between Federal Government Deposit and Loans and Advances (LAd).

The $P$ value of 0.050 , means that the $P$ value is statistically significant at $5 \%$ level. Since $t_{\text {cal }}(2.143)$ is outside our acceptance region (+/- 1.96), Therefore we reject the null hypothesis and uphold the alternative hypothesis. That is, there is significant impact of FG Deposit on Loans and Advances (LAd).

Therefore the TSA policy which seeks to reduce FG Deposit in the Commercial banks would significantly reduce Loans and Advances (LAd).

The following conclusions are inferred:

\section{Conclusion}

1. The TSA policy which seeks to reduce FG Deposit in the commercial banks would significantly reduce Credit to the Private Sector.

2. The TSA policy which seeks to reduce FG Deposit in the commercial banks would significantly reduce Deposit Mobilization.

3. The TSA policy which seeks to reduce FG Deposit in the commercial banks would significantly reduce Loans and Advances.

\section{Recommendation}

The banks should avoid over-reliance of government funds and source for funds from other sectors of the economy. Rural banking should be aggressively undertaken to mobilise funds from the un-banked among rural dwellers. The government should find other avenues to encourage the private sector. The policy however should not be killed by policy intricacies.

\section{Bibliography}

[1]. Eme, O. I., Chukwurah, D. C., \& Iheanacho, E. N. (2015, November). AN ANALYSIS OF PROS AND CONS TREASURY SINGLE ACCOUNT POLICY IN NIGERIA. Arabian Journal of Business and Management Review (OMAN Chapter), 5(4).

[2]. Isa, A. A. (2016). The Treasury Single Account (TSA) as an Instrument of Financial Prudence and Management: Prospects and Problems. Research Journal of Finance and Accounting, 7(4).

[3]. Kanu, C. (2016). Impact of Treasury Single Account on the Liquidity. ABC Journal of Advanced Research, 5(1), 43-52.

[4]. Lienert, I. (2009). Modernizing Cash Management, Technical Notes and Manuals, Fiscal Affairs Department. Washington: International Monetary Fund.

[5]. Obinna, C. (2015, August 11). Banks Face Liquidity Strain as FG Fully Enforces Treasury Single Account. p. 52.

[6]. Ocheni, S. (2016, January 25). Treasury Single Account: A catalyst for public financial management in Nigeria. The Nation.

[7]. Richard, T., Florence, M., \& Zénon, M. (2015). The Effects of Deposits Mobilization on Financial Performance in Commercial Banks in Rwanda. A case of Equity Bank Rwanda Limited. International Journal of Small Business and Entrepreneurs.

[8]. Rogers, E. (1995). Diffusion of innovations (4th ed.). New York: The Free Press.

[9]. Tari, V. A., Pwafeyeno, M., \& Minnessi, G. (2016). Treasury Single Account (TSA) Policy in Nigeria: Reviving Jonathan's 'Dead' Policy Directives. Online Journal of Social Sciences Research, 5, 6-12.

[10]. Yusuf, I., \& Chiejina, N. (2015, August 16). Anti-Graft War: One Economy, One Account. Sunday Nation, pp. 9-10,71.

[11]. Yusuf, M. (2016). Effects of Treasury Single Account on Public Finance. Research Journal of Finance and Accounting, 7(6). 
TABLE 4: Showing The Federal Government Deposit (Fg Dp), Credit To The Private Sector (Crp), Deposit Mobilisation (Dpm) And Loans And Advances (Lad) Of The Commercial Banks For The Period 2000-2015

\begin{tabular}{|l|l|l|l|l|}
\hline DATE & FG Dp (N'Billion) & CRP (N'Billion) & DPM (N'Billion) & L\&A (N'Billion) \\
\hline $\mathbf{2 0 0 0}$ & 73.8 & 530.37 & 343.17 & 508.3 \\
\hline $\mathbf{2 0 0 1}$ & 28.3 & 764.96 & 451.96 & 796.2 \\
\hline $\mathbf{2 0 0 2}$ & 52.6 & 930.49 & 556.01 & 954.6 \\
\hline $\mathbf{2 0 0 3}$ & 79.8 & 1096.54 & 655.74 & 1210.0 \\
\hline $\mathbf{2 0 0 4}$ & 117.2 & 1421.66 & 797.52 & 1519.2 \\
\hline $\mathbf{2 0 0 5}$ & 119.1 & 1838.39 & 1316.96 & 1976.7 \\
\hline $\mathbf{2 0 0 6}$ & 134.1 & 2290.62 & 1739.64 & 2524.3 \\
\hline $\mathbf{2 0 0 7}$ & 254.5 & 3680.09 & 2693.55 & 4813.5 \\
\hline $\mathbf{2 0 0 8}$ & 292.7 & 6941.38 & 4118.17 & 7799.4 \\
\hline $\mathbf{2 0 0 9}$ & 451.8 & 9147.42 & 5763.51 & 8912.1 \\
\hline $\mathbf{2 0 1 0}$ & 825.6 & 10157.02 & 5954.26 & 7706.4 \\
\hline $\mathbf{2 0 1 1}$ & 678.7 & 10660.07 & 6531.91 & 7312.7 \\
\hline $\mathbf{2 0 1 2}$ & 1113 & 14649.28 & 8062.10 & 8150.0 \\
\hline $\mathbf{2 0 1 3}$ & 2931.60 & 15751.84 & 8606.61 & 10005.6 \\
\hline $\mathbf{2 0 1 4}$ & 764.6 & 17129.68 & 11936.90 & 12889.4 \\
\hline $\mathbf{2 0 1 5}$ & 53.8 & 18674.15 & 11363.49 & 13086.2 \\
\hline Source: CBN STATISTICAL BULLETIN 2015 & & \\
\hline
\end{tabular}

